\section{ECONOMICS}

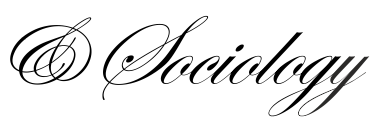

Esquivias, M. A., Sugiharti, L., Rohmawati, H., \& Sethi, N. (2021). Impacts and implications OF a pandemic on tourism demand in Indonesia. Economics and Sociology, 14(4), 133-150. doi:10.14254/2071-789X.2021/14-4/8

\title{
IMPACTS AND IMPLICATIONS OF A PANDEMIC ON TOURISM DEMAND IN INDONESIA
}

\author{
Miguel Angel Esquivias \\ Universitas Airlangga, \\ Surabaya, Indonesia \\ E-mail:miguel@,feb.unair.ac.id \\ ORCID 0000-0002-1282-6163 \\ Lilik Sugiharti \\ Universitas Airlangga, \\ Surabaya, Indonesia \\ E-mail: \\ sugiharti.lilik@ffeb.unair.ac.id \\ ORCID 0000-0001-5156-7929

\section{Hilda Rohmawati \\ Universitas Airlangga, \\ Surabaya, Indonesia \\ E-mail: bilda.robmawati- \\ 2016@ffeb.unair.ac.id}

\section{Narayan Sethi} \\ National Institute of Technology \\ Rourkela, Rourkela, India \\ E-mail:sethin@,nitrk..ac.in \\ ORCID 0000-0003-4298-4928
}

Received: June, 2021

1st Revision: November, 2021

Accepted: December, 2021

DOI: $10.14254 / 2071-$

789X.2021/14-4/8

JEL Classification: C32, C52, F14, F47

\begin{abstract}
This paper estimates the economic losses in Indonesia's tourism sector due to the COVID-19 pandemic using an Autoregressive Integrated Moving Average Model (SARIMA). Additionally, an autoregressive distributed lag model (ARDL) is employed to estimate the demand for tourism in Indonesia from the six largest inbound tourist countries, from 1989 to 2019. The results predict a decrease of nearly 16.65 million tourists and a potential loss of US $\$ 19.07$ billion from January 2020March 2021. Income per capita, relative prices, and substitution prices significantly impact the demand from overseas travelers for tourism opportunities in Indonesia. Tourism in Indonesia is considered as a luxury with a competitive price. The country could capitalize on the high willingness to pay of foreign tourists, strong income elasticity, and a positive perception of Chinese tourists. Complementary tourism promotion policies from neighboring countries could help to attract more Chinese visitors. Inbound tourism from India may experience the largest negative impact from COVID-19 due to the large income elasticity, negative price elasticity, and a possible substitution in destinations amid changes in prices. Tourists from Singapore and Australia may soon revisit as they see Indonesia as an inexpensive destination. Japan may revisit depending on whether tourism prices in Indonesia remain competitive or not. Policy makers may investigate non-price policies as price-oriented ones will not be very effective.
\end{abstract}

Keywords: tourism demand, COVID-19, international tourism, Indonesia, crisis, word of mouth, competitiveness, recovery, economic impact. 


\section{Introduction}

The COVID-19 pandemic caused a global reduction of nearly $75 \%$ in international tourist arrivals in 2020, leading to a sharp decrease in the income from tourism-related activities around the world estimated at US\$ 1.3 trillion. As countries imposed travel restrictions and limited mobility to curb virus transmission, international tourism receipts continued to fall. As a result, support tools for the recovery of confidence in the tourism sector, for the resumption of tourism activities and for compensation for losses incurred, are needed (Bakar \& Rosbi, 2020).

In 2019, Indonesia attracted nearly 16.1 million foreign travelers, which contributed US $\$ 17.6$ billion to the foreign currency and created an increase of more than $10 \%$ in direct and indirect jobs for the labor force. The Indonesian government is now seeking alternative strategies to reactivate its tourism industry. One approach it may take is to focus on boosting domestic visits while waiting for international borders to reopen. This could be followed by a focus on attracting regional visitors (from Asia and Oceania). Policy tools proposed to accompany such new targets include: first, a fiscal stimulus of IDR4.7 trillion for tourismrelated activities; second, travel incentives with a fund allocation of IDR299 billion aimed at promotion activities and supporting competitive prices via discounts; and third, encouragement for ministries and state-owned enterprises to arrange business trips to domestic tourist destinations. At the same time, efforts could be focused on improving hygiene, health and adherence to strict safety protocols to support the reopening of major tourist destinations.

Despite the important improvements in Indonesia's infrastructure, branding, human resources, and promotion policies in the last decade (Pujiharini \& Ichihashi, 2016; Rudenko $\&$ Tedjakusuma, 2018), Indonesian tourism today requires substantial support to accelerate its recovery from the impact of the COVID-19 pandemic. Hence, it is crucial to understand the drivers that might attract more tourists and improve services. For example, the pandemic is likely to have impacted the incomes of foreign tourists. Prices in Indonesia and other international destinations may have changed, which would affect the demand for tourism services (Esquivias et al., 2021). Besides, international competition rises as countries attempt to restore their own tourism activities with various support policies (World Bank, 2020).

By the end of 2020, the income from the six largest inbound tourist countries to Indonesia, had fallen substantially. The International Monetary Fund reported that in 2020 the annual GDP contracted by $2.4 \%$ in Australia, $5.4 \%$ in Singapore, $5.6 \%$ in Malaysia, $4.8 \%$ in Japan, and $8.0 \%$ in India. China was the only top inbound country partner to have grown their tourism sector, which they did by $2.3 \%$. A contraction of GDP may imply a decrease in disposable personal income. Additionally, the consumer price index of Thailand, Malaysia, Australia, Japan, Singapore, Hong Kong, and some and some European countries were expected to fall. Meanwhile, that of Indonesia was likely to increase. Both incomes and prices are essential elements in generating demand for tourism activities (Barman \& Nath, 2019; Gössling et al., 2020; Yazdi \& Khanalizadeh, 2017). Adjustments in relative prices would suggest that those alternative destinations could become more price-competitive than Indonesia.

Three main objectives are set for this study. First, we estimate Indonesia's losses due to the impact of COVID-19 on tourist arrivals in 2020 and 2021 by employing a Seasonal Autoregressive Integrated Moving Average Model. The losses are broken down into revenue related to transport, food and beverages, accommodation, shopping, tour packages, and other activities. Second, by employing an Autoregressive Distributed Lag model (ARDL), we estimate the role that incomes, relative price competitiveness, and substitution prices play in 
tourist visits to Indonesia from the top six largest countries of origin: Australia, Singapore, Malaysia, Japan, China, and India. We incorporate lag variables to measure the word-ofmouth effect, a key driver of tourism demand (Habibi, 2017; Song et al., 2003). Third, we integrate two large shocks that tourism in Indonesia has experienced - the global financial crisis in 2008-09 and the terrorist attack in 2005.

The SARIMA model employs monthly data of total tourism arrivals from January 2007 to December 2019. Subsequently, we estimate the projected arrivals for 2020 and 2021 (scenario of no pandemic) and compare the estimates to the actual arrivals. The difference is used to compute losses across tourism-related activities in 2020 and the first three months of 2021 (latest available data). We employ data from the Statistical Bureau of Indonesia (BPS) about the average total expenditure per tourist across accommodation, food and beverages, shopping, transportation, tour packages, and others. The ARDL model estimates demand for Indonesian tourism from the six largest inbound tourist countries within the Asian-Oceania region. Demand is modeled as a function of tourists' income, relative prices for tourism services, and alternative prices in top destinations reported for each of the six inbound countries. We employ annual data from 1989 to 2019.

Besides contributing to the literature of tourism demand and the forecasting of tourism earnings for Indonesia, we incorporate into the model a variable that captures the alternative prices benchmark, that is, the foreign competition. This has seldom been employed in previous studies about Indonesian tourism. We offer evidence from previous economic shocks (a financial crisis and a terrorist attack) that affected tourism arrivals which is relevant to the COVID-19 pandemic. A variable capturing the word-of-mouth effect is also estimated, using data from over a relatively long period of time. This study is contextual, as the tourism sector is vital for the Indonesian economy, and a recovery plan has never been needed more urgently due to the unprecedented impact of the prolonged pandemic (Gössling et al., 2020). A recovery plan is needed to create employment, increase foreign exchange, and encourage economic activities across sectors (Mahadevan et al., 2017).

In the last decade, the Indonesian government paid special attention to tourism activities by allocating the sector an extensive budget and investing heavily in the infrastructure projects needed to support the activities (Muryani et al., 2020). In 2018 alone, Indonesia proposed 10 new destinations (New Balis) and launched a massive tourism destination campaign, 'Wonderful Indonesia' in 2011 (Rudenko \& Tedjakusuma, 2018). However, the sector was exposed to shocks that obstructed the achievement of its ambitious targets: namely, the financial crisis of 2008, a terrorist attack, and natural disasters (Muryani et al., 2020; Purwomarwanto \& Ramachandran, 2015; Smyth et al., 2009; Song \& Lin, 2010).

During the COVID-19 pandemic, consumer prices and the incomes of overseas tourists are still adjusting to the changed financial environment, and this has altered the price competitiveness landscape. Prices of global tourism activities are expected to fall in the short run. China has seen prices in tourism-related activities adjusting in the post-pandemic period and willingness to pay for safer environments increasing (Qiu et al., 2020). Governments around the world are re-thinking their pre-pandemic strategies to reactivate their tourism sector, and this will result in higher competition over prices (Bakar \& Rosbi, 2020). Indonesia needs to anticipate how its competitors will strategize their resources to attract more tourists, reduce prices, and deal with the economic shocks suffered so far. A good understanding of demand will need to inform policy making to prevent further losses and to recover the sector. 


\section{Literature review}

Evidence has shown how tourism supports the national job creation, output growth and tax revenue, and provides extensive linkages between the different sectors of the economy (Brida et al., 2016; Dogru \& Bulut, 2018; Mahadevan et al., 2017). The demand function illustrates how tourism as an economic activity leads to output growth. Economic and non-economic factors play a role in explaining the dynamics of demand for tourism services (Habibi, 2017). Per capita income of the country of origin, installed capacity, relative prices, exchange rates, access, security, and infrastructure are common drivers of tourism demand (Assaf \& Tsionas, 2018; Barman \& Nath, 2019; Ghaderi et al., 2017; Kim et al., 2018). Commonly, the income of tourists and prices plays a crucial role in demand generation, signaling that economic slowdowns in the foreign countries could lead to a significant decrease in overseas tourism arrivals in Indonesia (Lim \& Won, 2020; Liu et al., 2018; Yazdi \& Khanalizadeh, 2017).

Tourism activities drive demand for both tourism consumption and investment, which eventually leads to their having direct and indirect effects on other sectors of the economy. Likewise, shocks in the sector could trigger negative spillovers that can decrease the demand for services, capital goods, and raw materials (Khalid et al., 2019). Shocks can lead to an economic slowdown across sectors, including transportation, communication, hospitality, the handicraft industry, consumer products, and restaurant services. Therefore, understanding the dynamics of tourism demand will help in the designing of effective policies that bolster the economy (Gössling et al., 2020; Joo et al., 2019).

Important factors in tourism that could negatively impact the industry's activities are shocks related to economics, politics, the environment, security, or health. Adverse shocks like terrorism attacks, the economic crisis of 2008, natural disasters, and pandemics entail decreases in real GDP, employment, export prices, and the consumer price index (Khalid et al., 2019; Purwomarwanto \& Ramachandran, 2015; Smeral, 2010; Smyth et al., 2009). As an example, the World Bank reported a fall in tourism arrivals in Indonesia of nearly $50 \%$ after the bombing attacks in 2002. The financial crisis in 2008 also led to a decline in arrivals and lower tourism expenditure, although it did signal a short-term recovery period.

The government's immediate response to shocks is crucial for recovering tourism activities. Free tourist visas, visa on arrival, marketing campaigns, discounts are often among the policy tools (Balli et al., 2013; Muryani et al., 2020; Song \& Lin, 2010). Previous studies found that shocks in the tourism sector are usually followed by transitory shocks, as well as recovery of activities after a short period (within months), but a slowdown in overall growth trends (Lean \& Smyth, 2009; Lim \& Won, 2020; Tang \& Wong, 2009). The impacts of pandemics on other countries, such as the MERS Outbreak on South Korea (2015), resulted in a loss of more than 2.1 million tourists in a year, equivalent to US $\$ 2.6$ to US\$3 billion loss in tourism-related activities (Joo et al., 2019).

Global revenue from tourism and related activities has decreased dramatically during the COVID-19 outbreak, impacting workers in related sectors and exacerbating income gaps (Polyzos et al., 2020; Williams, 2020). The COVID-19 pandemic may create a shock in the GDP of around $2 \%$ in developing countries and of nearly $1.8 \%$ in developed countries, with tourism as one of the most severely affected sectors (Maliszewska et al., 2020). Countries dependent on tourism incomes will suffer more (Fernandes, 2020). Decreasing GDP may well decrease tourism activities, leading to changes in price competitiveness (Lim \& Won, 2020). Disruption in prices could be exacerbated by governments' aggressive policy responses and by companies lowering prices to increase demand. Excess supply, low prices (lack of demand), and higher operating costs arising from compliance with health protocols (Zhang et al., 2020) 
may result in a deep fall for the international tourism sector. Anticipating changes in income, prices, and policies from other governments will become crucial for governments in restoring their tourism sectors in a post-pandemic era.

\section{Methodological approach}

This paper first applies a Seasonal Autoregressive Integrated Moving Average Model (SARIMA) to forecast monthly foreign tourist arrivals in January 2020 until March 2021, in line with the study by Chang and Liao (2010). The SARIMA model employs a static approach. The difference between the projected and the actual arrivals helps to estimate the losses across tourism-related activities (Joo et al., 2019). We employ data from the Statistical Bureau of Indonesia (BPS) as to the average spending per tourist on accommodation, food and beverages, shopping, transportation, and tour packages. Average tourism expenditure is estimated at US\$1,145.64 per foreign arrival in 2019. BPS provides a breakdown of the average allocation of international tourism receipts across main tourism activities in 2019. An average tourist allocates $38.55 \%$ of expenditure to accommodation, $21.15 \%$ to food and beverages, $14.63 \%$ to shopping, $13.91 \%$ to transportation, $1.55 \%$ to tour packages, and $10.21 \%$ to other components. We employ the SARIMA estimates and expenditure breakdown to project the monthly losses from January 2020 until March 2021, as in Chang and Liao (2010). Projections provided by the government of Indonesia (recovery scenario) are employed to estimate loses from April to December 2021.

Second, we estimate tourism demand from the six largest inbound tourist countries within the Asian-Oceania region: Australia, Singapore, Malaysia, Japan, China, and India. An ARDL estimates arrivals as a function of income, relative prices within Indonesia, and alternative prices in the top destinations reported for each of the six inbound countries. Prices in Indonesia are compared to those of its main tourist competitors (Table 1). The models are estimated by considering the annual data from 1989 to 2019; a lagged variable for arrivals to capture the effect of word-of-mouth; and a set of variables to measure the shocks from the financial crisis in 2008-09 and a terrorist attack in 2005.

Table 1. Top Tourism destination countries competing with Indonesia in 2019

\begin{tabular}{lcccc}
\hline & Top 1 & Top 2 & Top 3 & Top 4 \\
\hline Malaysia & Thailand & Singapore & Australia & Brunei \\
\hline Singapore & Malaysia & Japan & Thailand & Hong Kong \\
\hline China & Thailand & Japan & Philippines & United States \\
\hline Australia & New Zealand & United States & United Kingdom & Thailand \\
\hline Japan & United States & France & Singapore & Australia \\
\hline India & Thailand & Singapore & Malaysia & United States \\
\hline
\end{tabular}

Source: world tourism organization, 2019

To identify the appropriate ARIMA model (lags) for every country included in the model, the Akaike (AIC) and the Schwartz (SIC) information criteria selection tool is applied. Once variables are tested for stationarity, we perform the ARDL bound test proposed by Pesaran and Shin (1998). The test addresses the cointegrating relationship between variables under I(0) and/or I(1). A bound test for cointegration helps assess whether a stable and longrun relationship exists between the proposed variables. The estimation is specified as follows: 


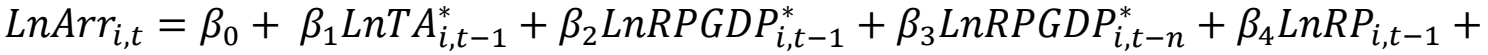

$$
\begin{aligned}
& \beta_{5} L n R P_{i, t-n}+\beta_{6} L n S P_{i, t-1}+\beta_{7} L n S P_{i, t-n}+D B_{-2005}+D C_{2009}+\varepsilon_{t}
\end{aligned}
$$

Where $T A_{i, t}$ is the logarithm of total tourist arrivals at year $t$ from country $i ; R P G D P_{i, t}$ is the per capita GDP of country $i$ at time $t ; R P_{i, t}$ is the tourism price in Indonesia relative to country $i$ at time $t$ measured by the consumer price index (CPI) and computed as $\mathrm{RP}_{\mathrm{i}, \mathrm{t}}=$ $\left(\mathrm{CPI}_{\text {IDN }, \mathrm{t}} / \mathrm{EX}_{\mathrm{IDN}, \mathrm{t}}\right) /\left(\mathrm{CPI}_{\mathrm{it}} / \mathrm{EX}_{\mathrm{it}}\right)$, where $\mathrm{CPI}_{\mathrm{IND}}$ and $\mathrm{CPI}_{\mathrm{i}}$ are $\mathrm{CPI}$ of Indonesia (IDN) and the source country $(i) . \mathrm{EX}_{\mathrm{it}}$ is the exchange rate of the country $i$ expressed in USD. $S P_{i, t}$ is an aggregate indicator of the substitute price determined by the top tourism destinations of country $i$ (see Table 1) and computed as in Dogru et al. (2017).

$S P_{i, t}=C P I_{I D N, t} /\left[\left(C P I_{T O P 1}+C P I_{T O P 2}+C P I_{T O P 3}+C P I_{T O P 4}\right)_{t} \times 25 \%\right] \times E R$

where $C P I_{I D N, t}$ is CPI of Indonesia at time t, $C P I_{T O P 1,2,3,4}$ are the CPIs of the top four alternative destination countries, and ER is the exchange rate of Indonesia (USD/IDR). The period is indicated by $t$ (annual data, year $t$ ). Two variable dummies are introduced in the model, one for a terrorist attack in 2005 in Bali $(D B)$ and a dummy to cover the global financial crisis in $2008(D C)$. $\varepsilon_{t}$ captures the random error term in each period, following N's distribution $\left(0, \sigma^{2}\right)$.

The ARDL model is tested using the error correction model (ECM) approach for cointegration. Following this, the short and long-run effects are estimated to capture the tourism demand. Once the error correction terms are generated, the ECM is estimated with the following rule:

$\Delta \operatorname{Arr}_{i, t}=\pi_{i 0}+\pi_{i R P G D P} \Delta R P G D P_{i, t}+\pi_{i, R P} \Delta R P_{i, t}+\pi_{i, S P} \Delta S P_{i, t}+\Delta D B_{2005}+\Delta D C_{2009}+$ $\pi_{i \varepsilon} \hat{\varepsilon}_{i, t-1}+\tau_{i t}$

The first-difference operator is represented by $\Delta$, and the error term is captured in $\tau_{i t}$. $\hat{\varepsilon}_{i, t-1}$ indicates the error correction term obtained as follows:

$$
\hat{\varepsilon}_{i, t-1}=T A_{i, t-1}-\beta_{0}-\beta_{2} R P G D P_{i, t-1}-\beta_{4} R P_{i, t-1}-\beta_{6} S P_{i, t-1}-D B_{-2005}+D C_{2009}
$$

Data on tourism arrivals is collected from the Bureau of Statistics in Indonesia (BPS) in annual series. Data on per capita GDP (RPGDP), consumer price index (CPI), and exchange rates $(\mathrm{EX})$ are collected from the World Development Indicators, International Financial Statistics, and CEIC Data.

\section{Results and analysis}

We split the results into two blocs; first, the SARIMA estimates with the computation of losses across activities, which focuses on the demand model (see Table 2 and Table 3); second, the tourism demand model using the ARDL approach, and the empirical testing of the data employed for both models.

\subsection{Economic looses in tourism in 2020}

The projections of tourism arrivals by employing the SARIMA approach cover the year 2020 as the COVID-19 outbreak. Reductions in tourism arrivals started in February 2020, and continued from April to December 2020. Travel restrictions were mainly 
introduced in March in Indonesia, while foreign countries started to impose restrictions in February 2020. China, the second-largest consumer of Indonesia tourism, had significantly reduced numbers of arrivals in Indonesia from December 2019.

The actual (column $\boldsymbol{a}$ in Table 2) minus projected arrivals (column b) are calculated to show the drop in the number of tourist arrivals (column c). Monetary losses (column e) are derived by multiplying the decrease in arrivals (c) by the average tourist expenditure in 2019 per foreign arrival (US\$1,220). Our results show a 32\% decrease in arrivals in February 2020 compared to the projected values, a further decrease of $69 \%$ in March, and a sharp decrease from April 2020 until March 2021 of nearly 90\%. Our estimates suggest the overall decrease in arrivals in January 2020 - March 2021 is 79\%, equivalent to nearly 16.65 million tourists cancelling trips to Indonesia, leading to a projected loss of US\$14.7 billion in 2020 and 4.3 million on the first three months of 2021 (Table 2). Accommodation activities loss was nearly US\$ 7.3 billion (Table 3), followed by food, US\$ 4.03 billion, retail, US\$ 2.7 billion, and transportation services, US\$ 2.6 billion. Tour package and other related activities suggest estimated losses of US\$295 million and US\$ 1.9 billion respectively.

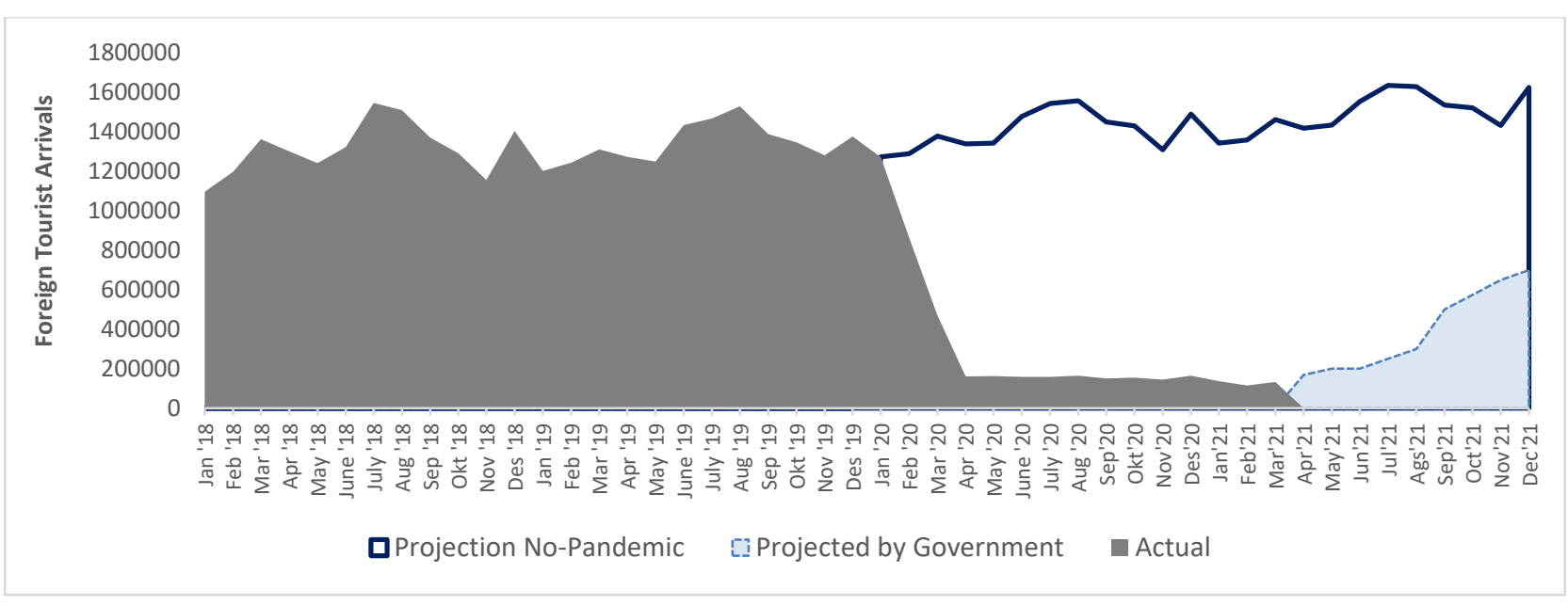

Graph 1. Actual arrivals and projected SARIMA Source: authors' data

Losses due to COVID-19 in Indonesia's international tourism sector are equivalent to $1.0 \%$ to $1.35 \%$ of GDP in 2020. Although the losses due to COVID-19 in tourism are small relative to the total GDP of Indonesia (1.167 Trillion US dollars estimated in 2020), the tourism sector is key to employment generation, to foreign exchange, and as a driver of growth for specific regions (e.g., Bali). Besides, the 79\% overall slowdown in 2020 is likely to cause severe disruption in the supply of tourism services.

The Indonesian government expected a gradual increase in foreign arrivals in May 2021. However, a more solid recovery could start in September 2021. We have included projections from April to December 2021 based on the prediction provided by the national government. The ministry of tourism aims to support the recovery of foreign tourist arrivals by targeting specific markets, focusing on high-quality tourism tour packages, organizing National and International events, and proposing a travel bubble with Malaysia, Singapore, Australia, and East Timor. 
Table 2. Estimated losses in tourism related activities in Indonesia 2020 and 2021 (projection)

\begin{tabular}{lccccc}
\hline & $\begin{array}{c}\text { Actual } \\
\text { (a) }\end{array}$ & $\begin{array}{c}\text { Projected } \\
\text { (b) }\end{array}$ & $\begin{array}{c}\text { Losses } \\
(\mathrm{c})=(\mathrm{b})- \\
(\mathrm{a})\end{array}$ & $\begin{array}{c}\text { Decrease } \\
(\mathrm{c}) /(\mathrm{d}) \times 100 \\
\%\end{array}$ & $\begin{array}{c}\text { Losses in Tourism Revenue million } \\
\text { US\$ }\end{array}$ \\
\hline January 2020 & 1.27 & 1.27 & 0.002 & $0.12 \%$ & 2 \\
\hline February 2020 & 0.86 & 1.29 & 0.43 & $33 \%$ & 493 \\
\hline March 2020 & 0.47 & 1.38 & 0.91 & $66 \%$ & 1043 \\
\hline April 2020 & 0.16 & 1.34 & 1.18 & $88 \%$ & 1352 \\
\hline May 2020 & 0.16 & 1.34 & 1.18 & $88 \%$ & 1512 \\
\hline June 2020 & 0.16 & 1.48 & 1.32 & $89 \%$ & 1581 \\
\hline July 2020 & 0.16 & 1.54 & 1.38 & $90 \%$ & 1604 \\
\hline August 2020 & 0.16 & 1.56 & 1.4 & $89 \%$ & 1489 \\
\hline September 2020 & 0.15 & 1.45 & 1.3 & $90 \%$ & 1466 \\
\hline October 2020 & 0.15 & 1.43 & 1.28 & $89 \%$ & 1524 \\
\hline November 2020 & 0.14 & 1.31 & 1.17 & $89 \%$ & 14,758 \\
\hline December 2020 & 0.16 & 1.49 & 1.33 & $89 \%$ & 1375 \\
\hline Total 2020 & 4.00 & 16.88 & 12.88 & $76.3 \%$ & 1421 \\
\hline January 2021 & 0.14 & 1.34 & 1.2 & $90 \%$ & 1524 \\
\hline February 2021 & 0.12 & 1.36 & 1.24 & $91 \%$ & 19,077 \\
\hline March 2021 & 0.13 & 1.46 & 1.33 & $91 \%$ & 11,742 \\
\hline $\begin{array}{l}\text { Total (January 2020 to March } \\
\text { 2021) }\end{array}$ & 4.39 & 21.04 & 16.65 & $79 \%$ & \\
\hline $\begin{array}{l}\text { April to Dec 2021* } \\
\text { projection) }\end{array}$ & 3.54 & 13.79 & 10.25 & $74.3 \%$ & \\
\hline
\end{tabular}

Notes. (a) Actual number of inbound tourists in millions. b) Projected number of tourists under scenario if no COVID-19 outbreak in millions. (c) Losses, millions of arrivals (difference between projected (b) and actual arrivals $(a)$ ). (e) Losses in revenue in million US\$. (d) monthly average expenditure per tourist arrival in US\$ 1,145.64 (BPS, 2020). *Estimation Based on Government Projections with intervention

Table 3. Estimated revenue losses in tourism activities Indonesia January to December 2020

\begin{tabular}{|c|c|c|c|c|}
\hline $\begin{array}{l}\text { Accommodation } \\
\text { (e) } \times 38.55 \%\end{array}$ & $\begin{array}{l}\text { Food and } \\
\text { Beverages } \\
\text { (e) } 21.15 \%\end{array}$ & $\begin{array}{l}\text { Shopping } \\
\text { (e) } 14.63 \%\end{array}$ & $\begin{array}{l}\text { Transport } \\
\text { (e) } 13.91 \%\end{array}$ & $\begin{array}{cc}\text { Tour } & \text { Others } \\
\text { Package } & \text { (e) } \times 10.21 \% \\
\text { (e) } \times 1.55 \% & \end{array}$ \\
\hline
\end{tabular}

\begin{tabular}{lcccccc}
\hline January 2020 & 0.9 & 0.5 & 0.3 & 0.3 & 0.04 & 0.2 \\
\hline February 2020 & 189.9 & 104.2 & 72.1 & 68.5 & 7.6 & 50.3 \\
\hline March 2020 & 401.9 & 220.5 & 152.5 & 145.0 & 16.2 & 106.4 \\
\hline April 2020 & 521.1 & 285.9 & 197.8 & 188.0 & 21.0 & 138.0 \\
\hline May 2020 & 521.1 & 285.9 & 197.8 & 188.0 & 21.0 & 138.0 \\
\hline June 2020 & 583.0 & 319.8 & 221.2 & 210.4 & 23.4 & 154.4 \\
\hline July 2020 & 609.5 & 334.4 & 231.3 & 219.9 & 24.5 & 161.4 \\
\hline August 2020 & 618.3 & 339.2 & 234.6 & 223.1 & 24.9 & 163.8 \\
\hline September 2020 & 574.1 & 315.0 & 217.9 & 207.2 & 23.1 & 152.1 \\
\hline October 2020 & 565.3 & 310.1 & 214.5 & 204.0 & 22.7 & 149.7 \\
\hline November 2020 & 516.7 & 283.5 & 196.1 & 186.4 & 20.8 & 136.9 \\
\hline December 2020 & 587.4 & 322.3 & 222.9 & 211.9 & 23.6 & 155.6 \\
\hline January 2021 & 530.0 & 290.8 & 201.1 & 191.2 & 21.3 & 140.4 \\
\hline February 2021 & 547.6 & 300.5 & 207.8 & 197.6 & 22.0 & 145.0 \\
\hline March 2021 & 587.4 & 322.3 & 222.9 & 211.9 & 23.6 & 155.6 \\
\hline $\begin{array}{l}\text { Total (Jan 2020 to } \\
\text { March 2021) }\end{array}$ & $7,354.3$ & $4,034.8$ & $2,791.0$ & $2,653.6$ & 295.7 & $1,947.8$ \\
\hline $\begin{array}{l}\text { Projected* April to } \\
\text { December 2021 }\end{array}$ & $4,526.54$ & 2483.43 & 1717.85 & 1633.31 & 182 & 1198.85 \\
\hline
\end{tabular}

Note: (e) Losses in Tourism Revenue million US\$ 


\subsection{Tourism demand}

As noted by Lin et al. (2015), tourism activities are often seasonal, and the datasets are frequently non-linear, with a tendency to report a positive growth. The determinants of tourism arrivals (such as tourist's income) commonly employed in tourism demand models, often show positive trends or are non-stationary. For instance, we first test the arrival data and the proposed set of variables for cointegration (Table 4). The cointegration test assesses whether there is equilibrium (stationarity) among the variables, while observing that each specific variable is non-stationary (Banerjee et al., 1994). We follow Pesaran et al. (2001) to test the cointegration among the variables proposed in the model, with the advantage of allowing for different integration orders in relation to other variables. This cointegration approach has been applied in the literature (Lin et al., 2015; Song \& Lin, 2010). The stationarity test for the data is carried out by employing an augmented Dickey-Fuller (ADF) test (Dickey \& Fuller, 1979).

The unit root test results indicate that the variable for tourism arrivals (nTA) is stationary at the first difference level for all countries except Singapore and Japan, which are stationary at the level and first difference. Similarly, we test the data on real GDP per capita (ln GDP), substitute prices (lnSP), relative price (ln RP), as well as the dummy variables for the terrorist bombing $(\operatorname{lnDB})$ and global financial crisis (ln DC). The results are displayed in, suggesting that all variables in all countries are stationary at the level or/and at the first difference. We estimate four models (Table 5) and choose the most appropriate one that can yield the most robust results.

Table 4. Unit root test results

\begin{tabular}{|c|c|c|c|c|c|c|c|c|}
\hline Countries & Stationar & evel & $\operatorname{lnTA}$ & lnRPGDP & $\operatorname{lnSP}$ & $\operatorname{lnRP}$ & DB & DC \\
\hline \multirow{5}{*}{ Malaysia } & \multirow{2}{*}{ Level (0) } & t-stat & -0.41 & -1.47 & -1.38 & -1.57 & $-5.68 * * *$ & $-3.88 * * *$ \\
\hline & & Prob. & 0.89 & 0.53 & 0.58 & 0.48 & 0.00 & 0.01 \\
\hline & \multirow{2}{*}{ First Diff (I) } & t-stat & $-4.33 * * *$ & $-4.06^{* * * *}$ & $-5.23 * * *$ & $-5.57 * * *$ & $-5.68 * * *$ & $-6.12 * * *$ \\
\hline & & Prob. & 0.00 & 0.00 & 0.00 & 0.00 & 0.00 & 0.00 \\
\hline & \multicolumn{2}{|l|}{ Selected Level } & $\mathrm{I}(\mathrm{I})$ & $\mathrm{I}(\mathrm{I})$ & $\mathrm{I}(\mathrm{I})$ & $\mathrm{I}(\mathrm{I})$ & $\mathrm{I}(0) \mathrm{I}(\mathrm{I})$ & $\mathrm{I}(0) \mathrm{I}(\mathrm{I})$ \\
\hline \multirow{5}{*}{ Singapore } & \multirow{2}{*}{ Level (0) } & t-stat & $-3.69 * * *$ & -1.43 & -1.33 & -1.62 & $-5.68 * * *$ & $-3.88 * * *$ \\
\hline & & Prob. & 0.01 & 0.56 & 0.60 & 0.46 & 0.00 & 0.01 \\
\hline & \multirow{2}{*}{ First Diff (I) } & t-stat & $-5.69 * * *$ & $-5.01 * * *$ & $-5.25 * * *$ & $-5.53 * * *$ & $-5.68 * * *$ & $-6.12 * * *$ \\
\hline & & Prob. & 0.00 & 0.00 & 0.00 & 0.00 & 0.00 & 0.00 \\
\hline & \multicolumn{2}{|l|}{ Selected Level } & $\mathrm{I}(0) \mathrm{I}(\mathrm{I})$ & $\mathrm{I}(\mathrm{I})$ & $\mathrm{I}(\mathrm{I})$ & $\mathrm{I}(\mathrm{I})$ & $\mathrm{I}(0) \mathrm{I}(\mathrm{I})$ & $\mathrm{I}(0) \mathrm{I}(\mathrm{I})$ \\
\hline \multirow{5}{*}{ China } & \multirow{2}{*}{ Level (0) } & t-stat & -1.06 & $-2.74 *$ & $-3.56^{* *}$ & -1.52 & -1.57 & $-3.18 * *$ \\
\hline & & Prob. & 0.71 & 0.08 & 0.02 & 0.50 & 0.48 & 0.04 \\
\hline & \multirow{2}{*}{ First Diff (I) } & t-stat & $-3.56^{* *}$ & -1.12 & $-4.89 * * *$ & $-4.87 * * *$ & $-7.50 * * *$ & $-4.74 * * *$ \\
\hline & & Prob. & 0.02 & 0.69 & 0.00 & 0.00 & 0.00 & 0.00 \\
\hline & \multicolumn{2}{|l|}{ Selected Level } & $\mathrm{I}(\mathrm{I})$ & $\mathrm{I}(0)$ & $\mathrm{I}(0) \mathrm{I}(\mathrm{I})$ & $\mathrm{I}(\mathrm{I})$ & $\mathrm{I}(\mathrm{I})$ & $\mathrm{I}(0) \mathrm{I}(\mathrm{I})$ \\
\hline \multirow{5}{*}{ Australia } & \multirow{2}{*}{ Level (0) } & t-stat & -0.87 & -1.42 & -1.37 & -1.43 & $-5.68 * * *$ & $-3.88 * * *$ \\
\hline & & Prob. & 0.78 & 0.56 & 0.58 & 0.55 & 0.00 & 0.01 \\
\hline & \multirow{2}{*}{ First Diff (I) } & t-stat & $-5.14 * * *$ & $-3.36^{* *}$ & $-5.24 * * *$ & $-5.19 * * *$ & $-5.68 * * *$ & $-6.12^{* * *}$ \\
\hline & & Prob. & 0.00 & 0.02 & 0.00 & 0.00 & 0.00 & 0.00 \\
\hline & \multicolumn{2}{|l|}{ Selected Level } & $\mathrm{I}(\mathrm{I})$ & $\mathrm{I}(\mathrm{I})$ & $\mathrm{I}(\mathrm{I})$ & $\mathrm{I}(\mathrm{I})$ & $\mathrm{I}(0) \mathrm{I}(\mathrm{I})$ & $\mathrm{I}(0) \mathrm{I}(\mathrm{I})$ \\
\hline \multirow{5}{*}{ Japan } & \multirow{2}{*}{ Level (0) } & t-stat & $-4.05 * * *$ & -1.53 & -1.41 & -1.60 & $-5.68 * * *$ & $-3.88 * * *$ \\
\hline & & Prob. & 0.00 & 0.50 & 0.56 & 0.47 & 0.00 & 0.01 \\
\hline & \multirow{2}{*}{ First Diff (I) } & t-stat & $-4.09 * * *$ & $-5.56^{* * *}$ & $-5.21 * * *$ & $-5.29 * * *$ & $-5.68 * * *$ & $-6.12^{* * *}$ \\
\hline & & Prob. & 0.00 & 0.00 & 0.00 & 0.00 & 0.00 & 0.00 \\
\hline & \multicolumn{2}{|l|}{ Selected Level } & $\mathrm{I}(0) \mathrm{I}(\mathrm{I})$ & $\mathrm{I}(\mathrm{I})$ & $\mathrm{I}(\mathrm{I})$ & $\mathrm{I}(\mathrm{I})$ & $\mathrm{I}(0) \mathrm{I}(\mathrm{I})$ & $\mathrm{I}(0) \mathrm{I}(\mathrm{I})$ \\
\hline \multirow{5}{*}{ India } & \multirow{2}{*}{ Level (0) } & t-stat & -0.31 & 2.50 & -1.39 & -1.25 & $-5.68 * * *$ & $-3.88 * * *$ \\
\hline & & Prob. & 0.91 & 1.00 & 0.58 & 0.64 & 0.00 & 0.01 \\
\hline & \multirow{2}{*}{ First Diff (I) } & t-stat & $-8.09 * * *$ & $-4.01 * * *$ & $-5.26 * * *$ & $-4.98 * * *$ & $-5.68 * * *$ & $-6.12^{* * *}$ \\
\hline & & Prob. & 0.00 & 0.00 & 0.00 & 0.00 & 0.00 & 0.00 \\
\hline & Selected Leve & & $\mathrm{I}(\mathrm{I})$ & $\mathrm{I}(\mathrm{I})$ & $\mathrm{I}(\mathrm{I})$ & $\mathrm{I}(\mathrm{I})$ & $\mathrm{I}(0) \mathrm{I}(\mathrm{I})$ & $\mathrm{I}(0) \mathrm{I}(\mathrm{I})$ \\
\hline
\end{tabular}

Notes: *,**,*** indicate $10 \%, 5 \%$, and $1 \%$ significance, respectively. I(O) indicates stationary at level and I(I) indicates stationary at first difference 
Additionally, we apply the bound test to determine a long-term stable cointegration relationship between the independent and dependent variables. The bound test coefficient (Fstatistic) is significant if the value is above the critical upper bound value (Pesaran et al., 2001; Srinivasan et al., 2012). All four models for the different countries have a significant bound coefficient (Table 6).

Table 5. Models employed

\begin{tabular}{lcccc}
\hline & Model 1 & Model 2 & Model 3 & Model 4 \\
\cline { 2 - 5 } Lag Tourism Arrivals -t (TA) & & Yes & Yes & \\
\hline Real Per Capita GDP (RPGDP) & Yes & Yes & Yes & Yes \\
\hline Substitute Prices (SP) & Yes & Yes & Yes & Yes \\
\hline Relative Prices (RP) & Yes & Yes & Yes & Yes \\
\hline Bomb Bali (DB) & & Yes & & Yes \\
\hline Financial Crisis (DC) & & Yes & Yes \\
\hline
\end{tabular}

Table 6. Bound test results

\begin{tabular}{lcccc}
\hline \multirow{2}{*}{ Countries } & \multicolumn{4}{c}{ F-statistic } \\
\cline { 2 - 5 } & Model 1 & Model 2 & Model 3 & Model 4 \\
\hline Malaysia & $20.19082^{* * *}$ & $4.143751^{* *}$ & $24.86599^{* * *}$ & $3.391931^{* *}$ \\
\hline Singapore & $7.739879^{* * *}$ & $5.958711^{* * *}$ & $3.632786^{*}$ & $4.148893^{* *}$ \\
\hline China & $28.83480^{* * *}$ & $4.594998^{* *}$ & $4.044667 * *$ & $8.455297^{* * *}$ \\
\hline Australia & $4.721546^{* * *}$ & $17.60629^{* * *}$ & $14.31679^{* * *}$ & $16.03610^{* * *}$ \\
\hline Japan & $3.288422^{*}$ & $7.94865^{* * *}$ & $10.96594^{* * *}$ & $14.88218^{* * *}$ \\
\hline India & $6.645808^{* * *}$ & $6.860587^{* * *}$ & $7.356762^{* * *}$ & $6.348938^{* * *}$ \\
\hline
\end{tabular}

Notes: *,**,***indicate $10 \%, 5 \%, 1 \%$ significance. The level of significance is based on the lower and upper bounds. 10\% (Lower Bound is 2.37 and the Upper Bound is 3.2), 5\% (LB 2.79-UB 3.67), $1 \%(L B 3.65-U B$ 4.66)

The ARDL estimation involves the unrestricted error correction model (UECM). The error correction term (ECT) captures the adjustment speed in response to deviations from the long-run equilibrium path. ECT is accepted when the value is negative and significant. This study indicates that all variables have a negative and significant ECT value for at least one of the models (Table 7). Although the ECT has a coefficient beyond -1, it suggests that instead of monotonically converging to the equilibrium path (as per usual), the correction course swings in a dampening way as noted in Narayan and Smyth (2006).

To choose the most appropriate model (out of the four proposed), we further perform a diagnostic test to look at heteroskedasticity, autocorrelation, and normality (Table 8).

We test all models for cointegration and verify that the models are free of potential normality, autocorrelation, and heteroscedasticity issues. In choosing the most appropriate model, it is necessary to consider the bound coefficient, following Nkoro and Uko (2016), who advise that a high bound coefficient is the best model for the ECM-ARDL model. The models chosen for each country are displayed in Table 8. Table 9 and In the short-run, the relative prices show an expected negative sign for Singapore, China, Japan, and India. As prices in Indonesia increase relative to living cost in the country of origin, a decrease in tourism is expected. By contrast, Australia has a positive coefficient, signaling a high perception of value in Indonesia's tourism services. As for the long run, the coefficients of relative prices are negative for Malaysia, Japan, and India, suggesting a decrease in demand on arrivals in Indonesia as the relative price rises. However, the coefficient of prices is less 
than one, indicating that they are price inelastic. This suggests that increases in prices do not result in a substantial decrease in demand. By contrast, China has a positive price elasticity, suggesting that Indonesia's higher prices may not discourage Chinese tourists from visiting.

The different perceptions in prices suggest that tourist promotion policies should be formulated differently based on sensitivity to prices. Policies directed towards Chinese and Australian tourists may focus on improving access, quality of services, experience, safety, and other non-price related aspects. As for Malaysians, Singaporeans, Japanese, and Indians, policies should consider price-related matters as they may help to reactivate tourism flows in the short and long run. Achieving competitive prices and increasing perception of value appear to be equally important, in line with the findings in previous studies (Barman \& Nath, 2019; Yazdi \& Khanalizadeh, 2017). Lim and Won (2020) found that Asians are less sensitive to prices in tourism in Las Vegas than Europeans, Canadians and Mexicans, advising that policies for Asians should be directed towards variety and diversification rather than price reduction.

Table 10. Long run ARDL estimation for Malaysia, Singapore, China, Australia, Japan, and India show the short and long-term ARDL results.

Table 7. Cointegration test results

\begin{tabular}{lcccc}
\hline \multirow{2}{*}{ Countries } & \multicolumn{4}{c}{ F-statistic } \\
\cline { 2 - 5 } & Model 1 & Model 2 & Model 3 & Model 4 \\
\hline Malaysia & $-1.514 * * *$ & $-1.037 * * *$ & $-1.244^{*}$ & $-0.520^{* * *}$ \\
\hline Singapore & $-1.467 * * *$ & 0.448 & $-0.897 * * *$ & $-0.271^{* * *}$ \\
\hline China & $-2.939 * * *$ & $-1.762 * * *$ & $-1.098^{* * *}$ & $-2.785^{* * *}$ \\
\hline Australia & $-0.744 * * *$ & $-0.227 * * *$ & 0.634 & $-0.140 * * *$ \\
\hline Japan & $-2.322 * * *$ & $-0.811^{* * *}$ & $-1.726 * * *$ & $-0.258^{* * *}$ \\
\hline India & $-3.370^{* * *}$ & $-2.679 * * *$ & $-0.763 * * *$ & $-0.863 * * *$ \\
\hline
\end{tabular}

Notes: $*, * *, * *$ indicate $10 \%, 5 \%$, and $1 \%$ significance, respectively

Table 8. Diagnostic tests results

\begin{tabular}{lcccccc}
\hline & Malaysia & Singapore & China & Australia & Japan & India \\
\hline Test & Model 2 & Model 1 & Model 1 & Model 2 & Model 4 & Model 2 \\
\hline Heteroskedasticity & 0.2990 & 0.1711 & 0.7984 & 0.5465 & 0.3092 & 0.4047 \\
\hline Autocorrelation & 0.3347 & 0.0867 & 0.1479 & 0.9116 & 0.0651 & 0.1623 \\
\hline Normality & 0.727949 & 0.982993 & 0.474502 & 0.756898 & 0.761496 & 0.660932 \\
\hline
\end{tabular}

Note: Significance at 5\%. Only selected models are displayed

\subsection{Discussion}

From the 1980s to the point when the Global Financial Crisis occurred in 2008, Singapore and Japan were the two largest Indonesian tourism consumers. Since 2009, Australia, China, India, and Malaysia have become fast-growing consumers (in the AsiaOceania region).

The variable capturing lag effect from previous arrivals suggests that there has been a positive sign for Malaysia, China, and India. As such, it indicates the significant presence of word-of-mouth effects, a theoretical and empirical concept captured in tourism demand (Salleh et al., 2008). The coefficient (word-of-mouth) is particularly crucial for India. A word- 
of-mouth effect may indicate persistence in the form of tourists returning to the destination (Habibi, 2017) or a positive recommendation that works as encouragement for other nationals to travel.

Income elasticity shows the response in tourism arrivals due to a change in the per capita income in the country of origin. In the short run (Table 9), Malaysia, Singapore, and China are income elastic, while the other countries show the opposite sign. A positive sign indicates that an increase in the per capita income leads to larger tourism arrivals. A negative coefficient may result in a decrease of tourism arrivals, likely as tourists shift to more highend destinations in periods of higher income per capita (Var et al., 1990). In the long run (Table 10), the effects of income are mainly positive. Income is an essential driver for tourism demand in Indonesia regardless of the country of origin. Malaysia, China, Australia, and India are income elastic, just as expected. Only the results for Japan are not significant. For Singapore, the coefficient is positive and significant, although lower than one. Low-income elasticity suggests that tourism in Indonesia may be considered affordable by the Singaporeans.

Table 9. Short run ARDL estimation for Malaysia, Singapore, China, Australia, Japan, and India

\begin{tabular}{|c|c|c|c|c|c|c|}
\hline Variables & Malaysia & Singapore & China & Australia & Japan & India \\
\hline & Model 2 & Model 1 & Model 1 & Model 2 & Model 4 & Model 2 \\
\hline $\mathrm{D}(\operatorname{LNTA}(-1))$ & $0.578 * * *$ & & $0.783 * * *$ & & $-0.403 * * *$ & $1.504 * * *$ \\
\hline D(LNTA(-2)) & $0.639 * * *$ & & & & & $1.499 * * *$ \\
\hline $\mathrm{D}(\operatorname{LNTA}(-3))$ & 0,301 & & & & & $0.849 * * *$ \\
\hline D(LNRPGDP) & $1.903 * * *$ & 0,601 & $26.186 * * *$ & $-0,596$ & $-2.410 * * *$ & $-5.753 * * *$ \\
\hline D(LNRPGDP(-1)) & & $-0,686$ & $4.488 * *$ & 1,797 & $-3.455 * * *$ & \\
\hline D(LNRPGDP(-2)) & & $-1.587 * *$ & $21.549 * * *$ & & & \\
\hline D(LNRPGDP(-3)) & & $-1.311 * *$ & & & & \\
\hline $\mathrm{D}(\mathrm{LNSP})$ & $-0,011$ & $1.162 * *$ & $-7.753 * * *$ & $-0.801 * * *$ & $0.434 * * *$ & $1.979 * * *$ \\
\hline $\mathrm{D}(\operatorname{LNSP}(-1))$ & & 0,469 & $4.099 * * *$ & $0.197 * * *$ & $-0.145 * * *$ & \\
\hline $\mathrm{D}(\mathrm{LNSP}(-2))$ & & 0,751 & & & & \\
\hline $\mathrm{D}(\operatorname{LNSP}(-3))$ & & $2.459 * * *$ & & & & \\
\hline $\mathrm{D}(\mathrm{LNRP})$ & 0,175 & $-1.081 *$ & $6.045 * * *$ & $0.679 * * *$ & $-0.773 * * *$ & $-1.899 * * *$ \\
\hline $\mathrm{D}(\mathrm{LNRP}(-1))$ & & $-0,178$ & $-2.759 * * *$ & & & \\
\hline $\mathrm{D}(\operatorname{LNRP}(-2))$ & & $-0,806$ & & & & \\
\hline $\mathrm{D}(\operatorname{LNRP}(-3))$ & & $-2.717 * * *$ & & & & \\
\hline $\mathrm{D}(\mathrm{DB})$ & $-0.068 *$ & & & $-0.361 * * *$ & & $-0.654 * * *$ \\
\hline $\mathrm{D}(\mathrm{DC})$ & & & & & $0.164 * * *$ & \\
\hline
\end{tabular}

Notes: *, **, *** indicate $10 \%, 5 \%$, and 1\% significance respectively. $C$ is $\beta 0$ or constant. Model chose under country name

A point worth noting is Australia's relatively large income elasticity, as it may be a threat in a post-pandemic period with a potential loss in disposable income. Indonesia, especially Bali, is a preferred destination for Australians. As countries like Australia are becoming more diversified in terms of preferred tourism destinations and interests (Seetaram et al., 2016), Indonesia will find it difficult to attract Australian tourists in the recovery period.

In the short-run, the relative prices show an expected negative sign for Singapore, China, Japan, and India. As prices in Indonesia increase relative to living cost in the country 
of origin, a decrease in tourism is expected. By contrast, Australia has a positive coefficient, signaling a high perception of value in Indonesia's tourism services. As for the long run, the coefficients of relative prices are negative for Malaysia, Japan, and India, suggesting a decrease in demand on arrivals in Indonesia as the relative price rises. However, the coefficient of prices is less than one, indicating that they are price inelastic. This suggests that increases in prices do not result in a substantial decrease in demand. By contrast, China has a positive price elasticity, suggesting that Indonesia's higher prices may not discourage Chinese tourists from visiting.

The different perceptions in prices suggest that tourist promotion policies should be formulated differently based on sensitivity to prices. Policies directed towards Chinese and Australian tourists may focus on improving access, quality of services, experience, safety, and other non-price related aspects. As for Malaysians, Singaporeans, Japanese, and Indians, policies should consider price-related matters as they may help to reactivate tourism flows in the short and long run. Achieving competitive prices and increasing perception of value appear to be equally important, in line with the findings in previous studies (Barman \& Nath, 2019; Yazdi \& Khanalizadeh, 2017). Lim and Won (2020) found that Asians are less sensitive to prices in tourism in Las Vegas than Europeans, Canadians and Mexicans, advising that policies for Asians should be directed towards variety and diversification rather than price reduction.

Table 10. Long run ARDL estimation for Malaysia, Singapore, China, Australia, Japan, and India

\begin{tabular}{lcccccc}
\hline Variables & Malaysia & Singapore & China & Australia & Japan & India \\
\hline & Model 2 & Model 1 & Model 1 & Model 2 & Model 4 & Model 2 \\
\hline LNRPGDP & $2.738^{* * *}$ & $0.876^{* *}$ & $3.457^{* * *}$ & $10.976^{* *}$ & $-4,762$ & $1.860^{* * *}$ \\
\hline LNSP & 0,381 & $-0,336$ & $-0.637^{* * *}$ & 0,465 & $1.040^{*}$ & $0.567^{* * *}$ \\
\hline LNRP & $-0.405^{*}$ & 0,165 & $0.925^{* * *}$ & $-1,369$ & $-0.900^{*}$ & $-0.628^{* * *}$ \\
\hline LNDB & $-0,038$ & & & $-4.438^{* * *}$ & $-2.394^{* *}$ & $-0,116$ \\
\hline LNDC & & & & $-1.211^{* *}$ & \\
\hline C & $-11.669^{* * *}$ & 6,445 & $-18.386^{* * *}$ & $-97,16$ & $59.404^{*}$ & $-3.519^{* *}$ \\
\hline
\end{tabular}

Notes: *,**, *** indicate $10 \%, 5 \%$, and $1 \%$ significance respectively. $C$ is $\beta_{0}$ or constant

As for substitute prices, in the short run Singapore, Japan, and India indicate a positive coefficient, signaling that a change in prices in Indonesia relative to its top competitors, may lead to substitution. It suggests that price competitiveness is vital for Indonesia as arrivals may decrease if the prices become less competitive relative to the substitute destinations. By contrast, the negative coefficient for Australia and China, in the short run, illustrates that top tourism destinations (see Table 1) are complementary destinations to Indonesia. Improvements in alternative destinations' competitiveness (e.g., Thailand) may support arrivals in Indonesia. This finding is in line with Habibi (2017), noting that Malaysia is a complementary tourism destination to China and Hong Kong or regional counterparts like Indonesia, Singapore, and Thailand.

Both relative and substitute prices suggest that Indonesia has relatively strong price competitiveness. On the one hand, main tourist inbound countries are not highly sensitive to relative prices, in line with previous studies' findings (Muryani et al., 2020; Ollivaud \& Haxton, 2019). On the other hand, Indonesia may take over tourists from those countries that are losing their price competitiveness. Still, the coefficients are relatively small, suggesting that becoming a substitute market may require substantial promotion efforts and 
improvements in access, skills, sustainability, digitalization, and quality of services (Ollivaud \& Haxton, 2019).

Our findings are in line with previous studies looking into the demand for tourism in South Korea (Kim et al., 2018), India (Barman \& Nath, 2019), which indicate that income, prices, and exchange rates are important determinants in the tourism demand models.

As for the dummy variables capturing shocks for the terrorist attack in Bali back in 2005 (DB), the effects are negative for tourism arrivals for all but those from Singapore and China. It should also be noted that only the coefficients for Australia and Japan are significant. In 2005, Japan and Australia were two of Bali's main tourist inbound countries. Tourist visits from Australia decreased significantly, as noted in the coefficient, both in the short and long run.

As for the global financial crisis of 2009, only tourists from Japan were greatly affected in the long run. Japan's results in the short run were positive, most probably because the impact of the crisis in Asia was felt only after several months of the slowdown in the West. It is worth noting that after 2009, the numbers of inbound tourists from Japan to Indonesia decreased (Xie \& Tveterås, 2020). The Japanese tourists have high purchasing power and are important contributors to Indonesia's income, but their tourism activities in Indonesia have been stagnant for the last ten years.

The findings indicate that reestablishing tourism activities after a shock may take time. The substantial losses incurred by the sector internationally may have shifted the supply and demand. An important point is that services should aim to maintain quality and follow protocols that may be key to tourism's reactivation. If Indonesia can maintain price competitiveness and support the quality of services, it may accelerate its recovery.

\section{Conclusion}

Tourism is one of the new engines of growth in Indonesia, generating a large number of jobs, bringing in foreign exchange, and creating ripple effects in the economy. Nevertheless, the COVID-19 pandemic is estimated as having been responsible for a decrease of nearly $76 \%$ of tourist arrivals in Indonesia in 2020. By employing a SARIMA model, this study estimates that Indonesia lost nearly 12.8 million tourists and US\$14.7 billion in 2020 . Accommodation related activities suffered more than $30 \%$ of the losses, and this was followed by large losses in the food and beverage services, retail, and transportation industries. Projections for 2021 indicate a potential loss of 14 million tourists and US\$ 17.1 billion.

Additionally, we estimate a tourism demand model as a function of lag in arrivals (word-of-mouth), income per capita, relative prices, substitution prices, and a set of variables to capture shocks in the global financial crisis in 2008 and a terrorist attack in 2005 . We look at Indonesia's top six inbound tourist countries, employing a series of data from 1989 to 2019. An autoregressive distributed lag model (ARDL) is applied to estimate tourism demand.

Overall, income level, relative prices, and substitution prices are important determinants of tourism arrivals. Additionally, the word-of-mouth effect is positive, signaling that tourists sharing information and experiences with one another are important sources for growth in arrivals in Indonesia. During the pandemic, attracting tourists from Japan, Singapore and India may take a long time as these countries are facing a decrease in disposable income and show large income elasticity. Luxurious goods in times of pandemic may take longer periods to rebound. Malaysia and China may resume tourism activities in Indonesia more rapidly than the other countries, provided that Malaysia does not experience a sharp economic slowdown. Singapore and Australia could resume at a relatively fast speed, 
mainly because Indonesia is perceived as an inexpensive tourism destination. Still, the recovery of Singapore and Australia tourists may depend on whether Indonesia improves the quality of services and implements safety protocols.

In the long run, the results suggest that in all cases but Japan, tourism is significantly determined by income levels. This may mean fewer visits in the medium- to long-term, hence requires policies to be adjusted accordingly. Meanwhile, tourist inflows from India are likely to be negatively affected by an income decrease, higher relative prices, and substitution prices. This warrants an even more strategic policy to prevent more losses.

Besides policies aimed at strengthening promotion and pricing, other policies related to health protocols and safety will be determinant aspects in the short-run. In more prolonged periods, it appears that attracting more tourists will require more than promotion and priceoriented policies, as the effects on demand from lower prices tend to be small. Policies failing to address quality of services, labor skills, access to points of interest, safety, and other noneconomic related policies, may have implications of low growth in tourism in the medium- to long-term. For now, policies seem aimed at maintaining the livelihood of tourism agents and reactivating tourism inflows. Once recovery is underway, a shift in policies towards more sustainable tourism activities is advisable.

China is the least affected country by the pandemic. A positive income elasticity of Chinese tourists suggests that the inflow of Chinese tourists visiting Indonesia may resume soon. Chinese tourists are less sensitive to prices in the long run and look at Indonesia as a complementary market to other Asian destinations. As it is likely that Asian countries e.g., Malaysia, Thailand, and the Philippines will focus on attracting Chinese tourists, Indonesia could be more aggressive in improving its tourism programs. The willingness of Chinese tourists in Indonesia to pay higher prices is another positive factor for the rapid recovery of tourism activities.

Pricing strategies may work to attract visitors from Malaysia, Japan, and India. However, an excessive focus on prices could be contra-productive, as the effects of lowering prices offers only a small positive effect on arrivals. Non-price policies may have a larger impact on international arrivals.

\section{Acknowledgements}

The authors are thankful to the Riset Mandat Hibah Penelitian Khusus COVID 19, Universitas Airlangga 2020.

\section{References}

Assaf, A.G., \& Tsionas, M. (2018). The estimation and decomposition of tourism productivity. Tourism Management, 65, 131-142. https://doi.org/10.1016/j.tourman.2017.09.004

Bakar, N. A., \& Rosbi, S. (2020). Effect of Coronavirus disease (COVID-19) to tourism industry. International Journal of Advanced Engineering Research and Science, 7(4), 189-193. https://doi.org/10.22161/ijaers.74.23

Balli, F., Balli, H. O., \& Cebeci, K. (2013). Impacts of exported Turkish soap operas and visafree entry on inbound tourism to Turkey. Tourism Management, 37, 186-192. https://doi.org/10.1016/j.tourman.2013.01.013

Banerjee, A., Dolado, J. J., Galbraith, J. W., \& Hendry, D. (1994). Co-integration, error correction, and the econometric analysis of non-stationary data. Oxford University Press. https://doi.org/10.1093/0198288107.001.0001 
Barman, H., \& Nath, H. K. (2019). What determines international tourist arrivals in India? Asia Pacific Journal of Tourism Research, 24(2), 180-190. https://doi.org/10.1080/10941665.2018.1556712

Brida, J. G., Cortes-Jimenez, I., \& Pulina, M. (2016). Has the tourism-led growth hypothesis been validated? A literature review. Current Issues in Tourism, 19(5), 394-430. https://doi.org/10.1080/13683500.2013.868414

Chang, Y.-W., \& Liao, M.-Y. (2010). A Seasonal ARIMA Model of Tourism Forecasting: The Case of Taiwan. Asia Pacific Journal of Tourism Research, 15(2), 215-221. https://doi.org/10.1080/10941661003630001

Dickey, D. A., \& Fuller, W. A. (1979). Distribution of the estimators for autoregressive time series with a unit root. Journal of the American Statistical Association, 74(366a), 427431. https://doi.org/10.1080/01621459.1979.10482531

Dogru, T., \& Bulut, U. (2018). Is tourism an engine for economic recovery? Theory and empirical evidence. Tourism Management, 67, 425-434. https://doi.org/10.1016/j.tourman.2017.06.014

Dogru, T., Sirakaya-Turk, E., \& Crouch, G. I. (2017). Remodeling international tourism demand: Old theory and new evidence. Tourism Management, 60, 47-55. https://doi.org/10.1016/j.tourman.2016.11.010

Esquivias, M. A., Sugiharti, L., Rohmawati, H., Setyorani, B., \& Anindito, A. (2021). Tourism demand in indonesia: Implications in a post-pandemic period. GeoJournal of Tourism and Geosites, 37(3), 951-958.

Fernandes, N. (2020). Economic effects of coronavirus outbreak (COVID-19) on the world economy. https://doi.org/10.2139/ssrn.3557504

Ghaderi, Z., Saboori, B., \& Khoshkam, M. (2017). Does security matter in tourism demand? Current Issues in Tourism, 20(6), 552-565. https://doi.org/10.1080/13683500.2016.1161603

Gössling, S., Scott, D., \& Hall, C. M. (2020). Pandemics, tourism and global change: A rapid assessment of COVID-19. Journal of Sustainable Tourism, 1-20.

Habibi, F. (2017). The determinants of inbound tourism to Malaysia: A panel data analysis. Current Issues in Tourism, 20(9), 909-930. https://doi.org/10.1080/13683500.2016.1145630

Joo, H., Maskery, B. A., Berro, A. D., Rotz, L. D., Lee, Y.-K., \& Brown, C. M. (2019). Economic Impact of the 2015 MERS Outbreak on the Republic of Korea's TourismRelated Industries. Health Security, 17(2), 100-108. https://doi.org/10.1089/hs.2018.0115

Khalid, U., Okafor, L. E., \& Shafiullah, M. (2019). The Effects of Economic and Financial Crises on International Tourist Flows: A Cross-Country Analysis. Journal of Travel Research, 59(2), 315-334. https://doi.org/10.1177/0047287519834360

Kim, J., Lee, C.-K., \& Mjelde, J. W. (2018). Impact of economic policy on international tourism demand: The case of Abenomics. Current Issues in Tourism, 21(16), 19121929. https://doi.org/10.1080/13683500.2016.1198307

Lean, H. H., \& Smyth, R. (2009). Asian financial crisis, avian flu and terrorist threats: Are shocks to Malaysian tourist arrivals permanent or transitory? Asia Pacific Journal of Tourism Research, 14(3), 301-321.

Lim, J., \& Won, D. (2020). How Las Vegas' tourism could survive an economic crisis? Cities, 100, 102643. https://doi.org/10.1016/j.cities.2020.102643

Lin, V. S., Liu, A., \& Song, H. (2015). Modeling and Forecasting Chinese Outbound Tourism: An Econometric Approach. Journal of Travel \& Tourism Marketing, 32(12), 34-49. https://doi.org/10.1080/10548408.2014.986011 
Liu, Y., Li, Y., \& Parkpian, P. (2018). Inbound tourism in Thailand: Market form and scale differentiation in ASEAN source countries. Tourism Management, 64, 22-36. https://doi.org/10.1016/j.tourman.2017.07.016

Mahadevan, R., Amir, H., \& Nugroho, A. (2017). Regional impacts of tourism-led growth on poverty and income inequality: A dynamic general equilibrium analysis for Indonesia. Tourism Economics, 23(3), 614-631. https://doi.org/10.5367/te.2015.0534

Maliszewska, M., Mattoo, A., \& van der Mensbrugghe, D. (2020). The Potential Impact of COVID-19 on GDP and Trade: A Preliminary Assessment. The World Bank. https://doi.org/10.1596/1813-9450-9211

Muryani, Permatasari, M. F., \& Esquivias, M. A. (2020). Determinants of Tourism Demand in Indonesia: A Panel Data Analysis. Tourism Analysis, 25(1), 77-89. https://doi.org/10.3727/108354220X15758301241666

Narayan, P.K., \& Smyth, R. (2006). What determines migration flows from low-income to high-income countries? An empirical investigation of Fiji-Us migration 1972-2001. Contemporary Economic Policy, 24(2), 332-342. https://doi.org/10.1093/cep/byj019

Nkoro, E., \& Uko, A. K. (2016). Autoregressive Distributed Lag (ARDL) cointegration technique: Application and interpretation. Journal of Statistical and Econometric Methods, 5(4), 63-91.

Ollivaud, P., \& Haxton, P. (2019). Making the most of tourism in Indonesia to promote sustainable regional development. Organisation for Economic Co-Operation and Development. https://doi.org/10.1787/c73325d9-en

Pesaran, M. H., \& Shin, Y. (1998). An autoregressive distributed-lag modelling approach to cointegration analysis. Econometric Society Monographs, 31, 371-413. https://doi.org/10.1017/CCOL0521633230.011

Pesaran, M. H., Shin, Y., \& Smith, R. J. (2001). Bounds testing approaches to the analysis of level relationships. Journal of Applied Econometrics, 16(3), 289-326. https://doi.org/10.1002/jae.616

Polyzos, S., Samitas, A., \& Spyridou, A. Ef. (2020). Tourism demand and the COVID-19 pandemic: An LSTM approach. Tourism Recreation Research, 1-13. https://doi.org/10.1080/02508281.2020.1777053

Pujiharini, F., \& Ichihashi, M. (2016). The Impact of Visa-Free Entry on the Determinants of Inbound Tourism Demand in Indonesia (No. 6-5; IDEC DP2 Series). Hiroshima University, Graduate School for International Development and Cooperation (IDEC). https://ideas.repec.org/p/hir/idecdp/6-5.html

Purwomarwanto, Y. L., \& Ramachandran, J. (2015). Performance of tourism sector with regard to the global crisis-A comparative study between Indonesia, Malaysia and Singapore. The Journal of Developing Areas, 49(4), 325-339. https://doi.org/10.1353/jda.2015.0149

Qiu, R. T. R., Park, J., Li, S., \& Song, H. (2020). Social costs of tourism during the COVID19 pandemic. Annals of Tourism Research, 84, 102994. https://doi.org/10.1016/j.annals.2020.102994

Revindo, M., Sabrina, S., \& Sawam, M. (2020). Dampak Pandemi COVID-19 terhadap Pariwisata Indonesia: Tantangan, Outlook, dan Respons Kebijakan. Lembaga Penyelidikan Ekonomi dan Masyarakat.

Rudenko, S., \& Tedjakusuma, A.P. (2018). “Wonderful Indonesia” country marketing campaign - how visible Indonesia as a tourism destination for Europeans. 186, 4. https://doi.org/10.2991/insyma-18.2018.44 
Salleh, N. H. M., Siong-Hook, L., Ramachandran, S., Shuib, A., \& Noor, Z. M. (2008). Asian tourism demand for Malaysia: A bound test approach. Contemporary Management Research, 4(4). https://doi.org/10.7903/cmr.1178

Seetaram, N., Forsyth, P., \& Dwyer, L. (2016). Measuring price elasticities of demand for outbound tourism using competitiveness indices. Annals of Tourism Research, 56, 6579. https://doi.org/10.1016/j.annals.2015.10.004

Smeral, E. (2010). Impacts of the World Recession and Economic Crisis on Tourism: Forecasts and Potential Risks. Journal of Travel Research, 49(1), 31-38. https://doi.org/10.1177/0047287509353192

Smyth, R., Nielsen, I., \& Mishra, V. (2009). 'I've been to Bali too'(and I will be going back): Are terrorist shocks to Bali's tourist arrivals permanent or transitory? Applied Economics, 41(11), 1367-1378. https://doi.org/10.1080/00036840601019356

Song, H., \& Lin, S. (2010). Impacts of the Financial and Economic Crisis on Tourism in Asia. Journal of Travel Research, 49(1), 16-30. https://doi.org/10.1177/0047287509353190

Song, H., Wong, K. K., \& Chon, K. K. (2003). Modelling and forecasting the demand for Hong Kong tourism. International Journal of Hospitality Management, 22(4), 435451. https://doi.org/10.1016/S0278-4319(03)00047-1

Srinivasan, P., Kumar, P. S., \& Ganesh, L. (2012). Tourism and economic growth in Sri Lanka: An ARDL bounds testing approach. Environment and Urbanization Asia, 3(2), 397-405. https://doi.org/10.1177/0975425312473234

Tang, T.C., \& Wong, K. N. (2009). Research note: The SARS epidemic and international visitor arrivals to Cambodia: is the impact permanent or transitory? Tourism Economics, 15(4), 883-890. https://doi.org/10.5367/000000009789955206

Var, T., Mohammad, G., \& Icoz, O. (1990). Factors affecting international tourism demand for Turkey. Annals of Tourism Research, 17(4), 606-610. https://doi.org/10.1016/0160-7383(90)90031-L

Williams, C.C. (2020). Impacts of the coronavirus pandemic on Europe's tourism industry: Addressing tourism enterprises and workers in the undeclared economy. International Journal of Tourism Research, jtr.2395. https://doi.org/10.1002/jtr.2395

World Bank. (2020). Rebuilding Tourism Competitiveness: Tourism Response, Recovery and Resilience to the COVID-19 Crisis. World Bank. https://doi.org/10.1596/34348

Xie, J., \& Tveterås, S. (2020). Economic drivers for the Chinese tourists. Scandinavian Journal of Hospitality and Tourism, 20(2), 110-125. https://doi.org/10.1080/15022250.2020.1734076

Yazdi, S.K., \& Khanalizadeh, B. (2017). Tourism demand: A panel data approach. Current Issues in Tourism, 20(8), 787-800. https://doi.org/10.1080/13683500.2016.1170772

Zhang, K., Hou, Y., \& Li, G. (2020). Threat of infectious disease during an outbreak: Influence on tourists' emotional responses to disadvantaged price inequality. Annals of Tourism Research, 84, 102993. https://doi.org/10.1016/j.annals.2020.102993 